\title{
Antibacterial Activity of Date Palm (PhoenixDectyliferaL.) Fruit at Different Ripening Stages \\ Saleh FA* and Otaibi MM
}

Department of Food and Nutrition Sciences, College of Agriculture and Food Science, King Faisal University, Saudi Arabia

\begin{abstract}
In vitro and in situ antibacterial activity of aqueous, ethanol, and ether extracts of three varieties of palm date (Khulase, Sheshi and Rezaz) in different maturation stages (Biser, Rutab and Tamer) were evaluated against some food borne pathogens. Gram positive bacteria showed higher sensitive against most extracts than Gram negative bacteria. Among the Gram positive bacteria, Listeria monocytogenesATCC 7644 and Staphylococcus saprophyticus ATCC 15305 recorded highest sensitive against most extracts. The ethanol followed by water extracts of Biser stage had a stronger antibacterial activity than other maturation stage for all varieties against Staphylococcus saprophyticus ATCC 15305. The results of Minimum Inhibitory Concentration (MIC) shows that Staphylococcus saprophyticus was very sensitive to the lowest concentration of ethanol extract of Rezaz variety at Biser stage $(\mathrm{RBOH}),(\mathrm{MIC}$, and $3.75 \mathrm{mg} / \mathrm{ml})$. RBOH was able to reduce the count of Staphylococcus saprophyticus in minced meat by above of $1 \mathrm{log}$ cycle during storage at $5^{\circ} \mathrm{C}$. This extracts $(\mathrm{RBOH})$ contained highest amount of phenolics (2035.3 mg/100g) compared to other extracts.
\end{abstract}

Keywords: Date palm; Date varieties; Date ripening stages; Antibacterial activity; Food borne pathogens

\section{Introduction}

Elevation of pathogenic bacterial contamination is one of the challenge factors which still cause food deterioration and serious diseases to humans around the world. Food borne illnesses are still a major concern for consumers, the food industry and food safety authorities. Meanwhile, consumers have been questioning the safety of synthetic preservatives of food. In recent decades an increasing tendency towards the use of natural substances instead of the synthetic ones has been observed. As the synthetic materials and products are more complex in comparison to natural substances, it will take a long time for them to complete their natural cycles and return to natural; thus causing a lot of environmental pollution. Also with the increase in the price of raw materials, the problem of cost benefits for chemical production is becoming more considerable. Food antimicrobials are the added or presented compounds in foods that hinder microbial growth or kill microorganisms. The functions of food antimicrobials are to inhibit or inactivate spoilage and pathogenic microorganisms. These functions have increased in importance in the past 10-15 years as food processors search for more and better tools to improve food safety especially those depending on the use of natural derivatives as antimicrobial agents [1].

Dates (Phoenixdectylifera L.) are an important nutritional source for many countries of the world, because the dates containing different nutrients such as carbohydrates, vitamins and minerals. From pollination to final date-fruit ripening takes 200 days. Date palm flowering and fruiting were recognized to have distinct stages over the ripening period. Hababauk, female flowers and immediate post-pollination period when the very young fruits are creamy white in color; Biser, sometimes named Kimri, green fruit undergoing rapid growth; Khalal, fruit grows slowly to full size, sugar content increasing while moisture content decreases, hard, glossy, red or yellow in color; Rutab, fruits ripening to a soft stage, brown in color; Tamar, fruits fully ripened, wrinkled, brown or black in color. All of the dates in different ripening stages containing various qualitative and quantitative amount of phytochemicals.
In recent decades an increasing tendency towards the use of natural substances as food additive instead of the synthetic ones has been observed. Natural phytochemicals, such as phenolic compounds, which extracted from many types of plants, are gaining importance that adds to foods, due to their benefits for human health, showed best antioxidant activity[2-9]. In addition to antioxidant activity, several studies demonstrated the antibacterial activity of phenols and/or phenolic extracts [2-9,10-13]. Besides nutritional values, dates are rich in phenolic and phytochemical components which changes during ripening stage [14-19] and may possessing antimicrobial activity. Several studies have been done on the antioxidant activity of dates $[20-23,15,17,18]$ but the literature review are poor about studies on the antibacterial activity of dates. Thus, the purpose of the present investigation was to investigate the antibacterial activity of dates ether ethanol, and water extracts in different ripening stages against some Gram-positive and Gram-negative bacteria in vitro and in situ (in food) in order to establish their biological activity for value.

\section{Materials and Methods}

\section{Palm date}

Three varieties of palm date (Khulase, Sheshi and Rezaz) were collected during maturation stages (Biser, Rutab and Tamer) during June to November, 2012, from Private El Ghanem farm. Date samples were dried directly after collection in under vacuum oven at $50^{\circ} \mathrm{C}$, milled and freezing storage until analysis.

*Corresponding author: Saleh FA,Department of Food and Nutrition Sciences College of Agriculture and Food Science, King Faisal University, Saudi Arabia, Tel: 0096635895756; Email: farag_ali@hotmail.com

Received November 10, 2013; Accepted December 09, 2013; Published December 30, 2013

Citation: Saleh FA, Otaibi MM (2013) Antibacterial Activity of Date Palm (PhoenixDectyliferaL.) Fruit at Different Ripening Stages. J Food Process Technol 4: 285. doi:10.4172/2157-7110.1000285

Copyright: (C) 2013 Saleh FA, et al. This is an open-access article distributed under the terms of the Creative Commons Attribution License, which permits unrestricted use, distribution, and reproduction in any medium, provided the original author and source are credited. 


\section{Preparation of extracts}

One hundred gram portions of dried date were separately homogenized (IKA, T18 basic Ultra-Turrax, for $5 \mathrm{~min}$ ) with $100 \mathrm{ml}$ solvents having an increasing polarity; diethyl ether, ethanol and distilled water. The mixtures were then left, in the dark, at room temperatures overnight. Theprior to filtration (Whatman No. 1) and centrifugation (Sorvall RC-5, Dupont, USA) at $5000 \mathrm{rpm}$ for $10 \mathrm{~min}$ at $5^{\circ} \mathrm{C}$. The clear extracts were membrane filtered $(0.45 \mu \mathrm{m})$ followed by dried under reduced pressure at $40^{\circ} \mathrm{CThe}$ dried extracts were refrigerated storage until use. The preparation of date extracts were done three times. The extraction yield is shown in Table 1.

\section{Microorganisms and growth conditions}

Table 2 lists microorganisms which were used to evaluate the antimicrobial activity of ether, ethanol and Water. Microbial strains were maintained at $5^{\circ} \mathrm{Cin}$ slants of Brain Heart Infusion (BHI, HIMEDIA, and Mumbai, India) plus 1.5\% Bacto-agar (Difco, USA). The other media used were Tryptic soy agar (TSA, Fluka, Switzerland) and Mueller- Hinton broth (Himedia, India) with $1.7 \%$ agar (MHA). Working cultures were activated in the respective broth at $30^{\circ} \mathrm{Cfor} 18 \mathrm{~h}$.

\section{In vitro evaluation of antibacterial activity of palm date extracts by agar well diffusion assay}

The agar well diffusion method was used for determination of in vitro antibacterial activity of palm date extracts. An actively growing indicator bacteria in a soft nutrient agar (Oxoid, Hampshire, UK) of $24 \mathrm{~h}$ culture at $35^{\circ} \mathrm{Cwere}$ spread on the surface of a nutrient agar plate medium (thickness of $5 \mathrm{~mm}$ ) with a sterile glass spreaders (hockey sticks) which was rotated several times. The plates were left for about $30 \mathrm{~min}$ to ensure an even distribution of inoculum. $0.1 \mathrm{~g}$ of each dried extractwas dissolved in $5 \mathrm{~mL}$ of methanol and water mixture (60: 40,

\begin{tabular}{|l|c|c|c|c|}
\hline \multirow{2}{*}{ Cultivars } & $\begin{array}{c}\text { Ripening } \\
\text { stages }\end{array}$ & \multicolumn{3}{|c|}{ Extraction yield (g/100g) on dry weight basis* } \\
\hline & & Ether & Ethanol & Water \\
\hline Khulase & Biser & $10.15 \pm 1.21$ & $29.56 \pm 0.99$ & $13.84 \pm 1.65$ \\
\hline & Rutab & $10.01 \pm 0.92$ & $32.28 \pm 2.65$ & $31.29 \pm 3.56$ \\
\hline & Tamer & $8.25 \pm 0.73$ & $78.45 \pm 3.98$ & $66.48 \pm 4.58$ \\
\hline Sheshi & Biser & $12.17 \pm 1.01$ & $29.12 \pm 2.11$ & $25.75 \pm 2.35$ \\
\hline & Rutab & $10.48 \pm 1.32$ & $32.70 \pm 2.99$ & $26.93 \pm 1.56$ \\
\hline & Tamer & $10.55 \pm 0.52$ & $81.61 \pm 4.65$ & $80.52 \pm 5.23$ \\
\hline Rezaz & Biser & $9.14 \pm 0.75$ & $29.49 \pm 1.62$ & $12.28 \pm 2.31$ \\
\hline & Rutab & $12.23 \pm 0.81$ & $28.51 \pm 2.51$ & $25.51 \pm 2.56$ \\
\hline & Tamer & $8.47 \pm 0.28$ & $67.83 \pm 3.93$ & $73.25 \pm 5.18$ \\
\hline
\end{tabular}

*(Mean values $\pm \mathrm{SD}), \mathrm{n}=3$

Table 1: The extraction yield of date cultivars ether, ethanol, and water extracts at various ripening stages. $\mathrm{v} / \mathrm{v}),(20 \mathrm{mg} / \mathrm{mL})$, then filter-sterilized by $0.45 \mu \mathrm{m}$ syringe filter. Three holes were punched out of the agar, by using a sterile cork borer of $6 \mathrm{~mm}$ diameter. The well was filled by $100 \mu \mathrm{L}$ of the sterilized supernatants of each extract $(2 \mathrm{mg} /$ well). The plates were incubated until zones of inhibition have clearly developed. The diameter of the complete inhibition zones was measured, including the well diameter. Zones are measured to the nearest whole number in millimeter, using transparent ruler. The antibacterial activity of date extractswas compared to the activity of both antibiotics, chloramphenicol (Riyadh Pharma, Saudi Arabia) and sulfadimidin (interchemie, Holland). The results are presented as the means of duplicate.

\section{Minimum inhibitory concentration (MIC)}

The agar dilution method of Clinical and Laboratory Standard Institute, CLSL, (2006) was adopted to perform the MIC using Mueller-Hinton Agar, (MHA, CM0337, Oxoid) against Staphylococcus saprophyticus ATCC 15305. These bacterial strain and chloramphenicol were, respectively, used as the control strains and reference antibiotic. The stock solution of the antibiotic was prepared in potassium phosphate buffer $(\mathrm{pH} 8.0,0.1 \mathrm{M})$ and diluted in buffer ( $\mathrm{pH}$ 6.0, 0.1 $\mathrm{M})$ to make working solutions ( 1000 and $100 \mathrm{mg} / \mathrm{L}$ ). Those solutions were sterilized with $0.45 \mu \mathrm{mAcrodiscfilter}$ (Gelman, USA).The media Muller-Hinton Agar (MHA) were aseptically added to sterile glass tubes containing extracts or the antibiotic. Negative controls water/ methanol $(40 / 60, \mathrm{v} / \mathrm{v})$ were also used under the same conditions. The content (final volume $20 \mathrm{ml}$ ) of each tube was gently mixed and poured in Petri plates. The final concentrations of extracts were $0-20 \mathrm{mg} / \mathrm{mL}$ whereas that of chloramphenicol was 0.001 and $0.005 \mathrm{mg} / \mathrm{mL}$. After hardening, the agar media were spotted with $5 \mu \mathrm{L}$ (104cfu) of the tested bacterium. The spots were left to dry and then plates were inverted followed by incubation at $30^{\circ} \mathrm{Cfor} 12-48 \mathrm{~h}$. The MIC was defined as the lowest concentration $(\mathrm{mg} / \mathrm{mL})$ of the extract resulting in no growth of bacteria. The test was conducted three times.

\section{In situ (In food) evaluation of antibacterial activity of palm date extracts}

The in situ assay was performed against Staphylococcus saprophyticus ATCC 15305 in minced camel meat as food module. Pure colonies of Staphylococcus saprophyticus ATCC 15305 taken from plate count agar (Oxoid CM 463, UK) were suspended in $0.85 \% \mathrm{NaCl}$, and the concentration adjusted with the Spectrophotometer to give $3 \times 10^{8} \mathrm{cfu} /$ $\mathrm{mL}$ (as $0.5 \pm 0.01 \mathrm{OD}$ at $625 \mathrm{~nm}$ equal $3 \times 10^{8}$ )[24]. This suspension was then serially diluted in maximum recovery diluent to give a suspension of $1 \times 10^{6} \mathrm{cfu} / \mathrm{mL}$. Under aseptic condition, $200 \mathrm{~g}$ of the meat (obtained from local super market) was placed into stomacher plastic page, inoculated with $20 \mathrm{ml}$ of cell suspension (give an initial contamination rate of around $1 \times 10^{5} \mathrm{cfu} / \mathrm{g}$ of meat) and mixed well with the Stomacher Lab Blender (Lab Blender, 400\UK). The meat divided into two portions, each portion was $100 \mathrm{~g}$ in stomacher plastic pages, the first

\begin{tabular}{|l|l|l|}
\hline Microorganism & Strain & Origin \\
\hline Escherichia coli & ATCC 25922 & American Type Culture Collection \\
\hline Pseudomonas aeruginosa & ATCC 27853 & American Type Culture Collection \\
\hline Salmonella enterica & ATCC 13076 & American Type Culture Collection \\
\hline Listeria monocytogenes & ATCC 7644 & American Type Culture Collection \\
\hline Staphylococcus saprophyticus & ATCC 15305 & American Type Culture Collection \\
\hline Staphylococcus aureus & ATCC 25923 & American Type Culture Collection \\
\hline Staphylococcus aureus & ATCC 29213 & American Type Culture Collection \\
\hline
\end{tabular}

Table 2: Microorganisms which were used to evaluate the antimicrobial activity. 
Citation: Saleh FA, Otaibi MM (2013) Antibacterial Activity of Date Palm (PhoenixDectyliferaL.) Fruit at Different Ripening Stages. J Food Process Technol 4: 285. doi:10.4172/2157-7110.1000285

Page 3 of 6

one was resaved as control and the other portion was mixed with the 5 $\mathrm{g}$ of dried ethanol extract of Rezaz variety at Biser stage dissolved in 10 $\mathrm{ml}$ saline solution. The samples were refrigerated storage and the counts of Staphylococcus saprophyticus were measured every 3 days.

\section{Determination of total content of phenolic compounds}

The Total Content of Phenolic Compounds (TPC) in samples was determined according to the method reported by Boyer and Hai Liu [25] with some modifications. One $\mathrm{ml}$ of extract was mixed with 1 $\mathrm{mL}$ of $10 \%$ Folin-Ciocalteu reagent in distilled water and $4 \mathrm{ml}$ of $7.5 \%$ sodium carbonate solution. The samples were maintained at room temperature for $30 \mathrm{~min}$ with periodical mixing, the absorbance at 765 $\mathrm{nm}$ was measured. The calibration curve was constructed within the concentration range $0.075-0.6 \mathrm{mg} / \mathrm{mL}$ of gallic acid. Mean values were calculated from three parallel analyses. Results were calculated as gallic acid equivalents in $\mathrm{mg} / 100 \mathrm{~g}$ of dry plant material using the following equation:

$$
\mathrm{C}=\mathrm{a} \times \gamma \times(\mathrm{V} / \mathrm{m}) \times 100
$$

Where: C: total amount of phenolic compounds, $\mathrm{mg} / 100 \mathrm{~g}$ as gallic acid; a: dilution number; $\gamma$ : concentration obtained from calibration curve $(\mathrm{mg} / \mathrm{mL})$; V: volume of aqueous ethanol used for extraction; $\mathrm{m}$ : weight of sample (g).

\begin{tabular}{|c|c|c|c|c|c|c|c|c|c|}
\hline \multirow[t]{2}{*}{ Cultivars } & \multirow[t]{2}{*}{$\begin{array}{l}\text { Ripening } \\
\text { stages }\end{array}$} & \multirow[t]{2}{*}{ Extracts } & \multicolumn{6}{|c|}{ Diameter of inhibition zone $(\mathrm{mm})$} & \multirow[b]{2}{*}{$\begin{array}{c}\text { Staph. aureus } \\
\text { ATCC } 29213\end{array}$} \\
\hline & & & $\begin{array}{c}\text { E. coli } \\
\text { ATCC } 25922\end{array}$ & $\begin{array}{l}\text { Pseudomonas } \\
\text { aeruginosa } \\
\text { ATCC } 27853\end{array}$ & $\begin{array}{l}\text { Salmonellaenterica } \\
\text { ATCC } 13076\end{array}$ & \begin{tabular}{|c|} 
Listeria \\
monocytogenes \\
ATCC 7644
\end{tabular} & $\begin{array}{l}\text { Staph. } \\
\text { saprophyticus } \\
\text { ATCC } 15305\end{array}$ & $\begin{array}{c}\text { Staph. aureus } \\
\text { ATCC } 25923\end{array}$ & \\
\hline \multirow[t]{9}{*}{ Khulase } & Biser & Ether & ND & $10.5 \pm 1.0^{\mathrm{cd}}$ & ND & $12 \pm 0.5^{\mathrm{gh}}$ & $13.5 \pm 0.0^{9}$ & $17.5 \pm 0.5^{c}$ & $16.5 \pm 0.0^{c}$ \\
\hline & & Ethanol & ND & $9 \pm 0.5^{d}$ & ND & $20 \pm 1.0^{c}$ & $35 \pm 0.1^{b}$ & $15 \pm 0.5^{d}$ & $15 \pm 1.0^{\mathrm{d}}$ \\
\hline & & Water & ND & ND & ND & $16.5 \pm 0.0^{\mathrm{de}}$ & $14 \pm 0.5^{f}$ & ND & ND \\
\hline & Rutab & Ether & ND & ND & ND & $13 \pm 0.5^{f}$ & $9.5 \pm 1.0$ & $8.5 \pm 1.0^{g}$ & $11 \pm 0.5^{\mathrm{fg}}$ \\
\hline & & Ethanol & ND & ND & ND & $13 \pm 0.0^{f}$ & $31 \pm 0.0^{c}$ & ND & ND \\
\hline & & Water & ND & $8.5 \pm 0.5^{d}$ & ND & $15 \pm 0.5^{\mathrm{e}}$ & $10 \pm 0.5^{\mathrm{h}}$ & $9 \pm 0.5^{\mathrm{fg}}$ & $12 \pm 0.0^{\mathrm{ef}}$ \\
\hline & Tamer & Ether & ND & $11 \pm 0.5^{c}$ & ND & $12.5 \pm 0.5^{\mathrm{fg}}$ & $10 \pm 0.5^{\mathrm{h}}$ & ND & $12 \pm 0.5^{\mathrm{ef}}$ \\
\hline & & Ethanol & ND & ND & ND & $14.75 \pm 1.0^{\text {ef }}$ & $29 \pm 0.5^{d}$ & ND & ND \\
\hline & & Water & ND & $10.25^{c d}$ & ND & $12.5 \pm 0.0^{f g}$ & $29.5 \pm 0.5^{\mathrm{cd}}$ & ND & $10 \pm 0.5^{\mathrm{gh}}$ \\
\hline \multirow[t]{9}{*}{ Sheshi } & Biser & Ether & ND & $9 \pm 1.0^{d}$ & ND & $17.5 \pm 0.0^{d}$ & $17 \pm 0.0^{\mathrm{e}}$ & $12.5 \pm 1.0^{\mathrm{e}}$ & $11.5 \pm 0.5^{\mathrm{fg}}$ \\
\hline & & Ethanol & ND & $10 \pm 0.5^{\mathrm{cd}}$ & ND & $16 \pm 1.0^{\mathrm{de}}$ & $30 \pm 0.5^{\mathrm{cd}}$ & $12.5 \pm 0.5^{\mathrm{e}}$ & $16.5 \pm 0.5^{c}$ \\
\hline & & Water & ND & $9 \pm 0.0^{d}$ & ND & $15.5 \pm 1.5^{\mathrm{e}}$ & $29 \pm 1.0^{d}$ & $9.5 \pm 0.5^{\mathrm{fg}}$ & $10.5 \pm 0.0^{g h}$ \\
\hline & Rutab & Ether & ND & ND & ND & $12 \pm 0.0^{g h}$ & ND & $9 \pm 0.0 \mathrm{fg}^{\mathrm{g}}$ & $10 \pm 0.0^{g h}$ \\
\hline & & Ethanol & ND & ND & ND & $12 \pm 0.0^{g h}$ & $31 \pm 0.5^{c}$ & ND & $9 \pm 0.0^{h}$ \\
\hline & & Water & ND & ND & ND & $15 \pm 0.5^{\mathrm{e}}$ & $9 \pm 0.0^{h}$ & ND & $11 \pm 0.0^{\mathrm{fg}}$ \\
\hline & Tamer & Ether & ND & $13.5 \pm 1.5^{b}$ & ND & $9.5 \pm 0.0^{\mathrm{h}}$ & ND & ND & $9 \pm 0.0^{\mathrm{h}}$ \\
\hline & & Ethanol & ND & ND & ND & $12.5 \pm 1.0^{\mathrm{fg}}$ & $35.5 \pm 1.0^{\mathrm{b}}$ & ND & $8 \pm 0.0^{h}$ \\
\hline & & Water & ND & ND & $9 \pm 0.0^{d}$ & $12.5 \pm 0.5^{\mathrm{fg}}$ & $29.5 \pm 0.5^{\mathrm{cd}}$ & ND & $8.5 \pm 0.0^{h}$ \\
\hline \multirow[t]{11}{*}{ Rezaz } & Biser & Ether & ND & ND & ND & $15.5 \pm 0.5^{e}$ & ND & $10 \pm 0.0^{f}$ & $10.5 \pm 1.0^{g h}$ \\
\hline & & Ethanol & ND & ND & ND & $15.5 \pm 1.5^{\mathrm{e}}$ & $37.5 \pm 0.5^{\mathrm{a}}$ & ND & $10.5 \pm 1.0^{g h}$ \\
\hline & & Water & ND & ND & ND & $14.5 \pm 1.0^{\text {ef }}$ & $30 \pm 0.5^{c d}$ & ND & $8.5 \pm 0.5^{h}$ \\
\hline & Rutab & Ether & $11 \pm 1.0^{c}$ & ND & ND & $12 \pm 0.0^{g h}$ & ND & ND & $8.5 \pm 0.5^{\mathrm{h}}$ \\
\hline & & Ethanol & ND & ND & $12 \pm 0.0^{c}$ & $13 \pm 0.5^{f}$ & ND & ND & ND \\
\hline & & Water & ND & ND & $11 \pm 1.0^{c}$ & $15.5 \pm 0.5^{\mathrm{e}}$ & ND & ND & ND \\
\hline & Tamer & Ether & ND & ND & ND & $12 \pm 0.5^{\mathrm{gh}}$ & $12.5 \pm 0.0^{g}$ & ND & $13 \pm 0.5^{\mathrm{e}}$ \\
\hline & & Ethanol & ND & ND & ND & $12.5 \pm 0.0^{f g}$ & ND & ND & $8.5 \pm 0.5^{h}$ \\
\hline & & Water & ND & ND & ND & $11 \pm 0.0^{\mathrm{h}}$ & ND & $13 \pm 0.0^{e}$ & ND \\
\hline & & $\mathrm{Chl}$ & $44 \pm 1^{\mathrm{a}}$ & $33 \pm 1.0^{\mathrm{a}}$ & $48 \pm 0.0^{\mathrm{a}}$ & $60 \pm 0.0^{\mathrm{a}}$ & ND & $46 \pm 0.0^{\mathrm{a}}$ & $46 \pm 1.0^{\mathrm{a}}$ \\
\hline & & Sul & $30 \pm 1^{b}$ & ND & $26 \pm 0.0^{\mathrm{b}}$ & $30 \pm 0.0^{b}$ & $38 \pm 0.0^{a}$ & $32 \pm 0.0^{b}$ & $33 \pm 1.0^{\mathrm{b}}$ \\
\hline
\end{tabular}

a-h Mean values ( $\pm \mathrm{SD} ; \mathrm{n}=6$ ) within the same column bearing different superscripts are significantly different $(P>0.05)$

Chl: chloramphenicol, $25 \mathrm{mg} / \mathrm{ml}$

Sul:sulfadimidin, $100 \mathrm{mg} / \mathrm{ml}$

ND: Not Detected

Table 3: : Antibacterial activity (Diameter of inhibition zone $\mathrm{mm}$ ) of date cultivars extracts at various ripening stages against pathogenic bacteria. 


\section{Determination of pigments content}

To prepare the extracts, a modified version of a previously published method [26] was used. Samples were soaked in methanol $(1 \mathrm{~g}$ plant material per $2 \mathrm{~mL}$ methanol) for $24 \mathrm{~h}$ in refrigerator. The liquid was removed, and solid parts were soaked again in methanol. Extracts were combined and stored in refrigerator prior to analysis. The carotenoids fraction was measured in a UV spectrophotometer at $470 \mathrm{~nm}$ [27]. To determine the concentration of anthocyanin's the absorbance at $550 \mathrm{~nm}$ was determined and anthocyanin concentration was calculated using an extinction coefficient of 33000 mol-1 cm-1[28].

\section{Statistical Analysis}

Three independent experiments were performed. All analysis and enumeration were done in duplicate. All data were analyzed by ANOVA using the general models procedure of SAS (1989) [29]. Differences among means were tested for significance $(\mathrm{P}>0.05)$ by Duncan's multiple range test.

\section{Results and Discussion}

\section{In vitro Antibacterial activity of extracts}

The antibacterial activity of date cultivars extracts at various ripening stages against some pathogenic bacteria are tabulated in Table 3. The results of the disk diffusion method indicated that ether, ethanol and water extracts of the three cultivars dates in different maturation stages showed different degrees of growth inhibition, depending on the bacterial strains. All tested extracts recorded stronger antibacterial activity against Gram positive bacteria than Gram negative bacteria. It has been stated that Gram negative bacteria are more resistant to various antibacterial against than Gram positive bacteria due to their outer lipopolysaccharide membrane cell [30,12,31].However, Listeria monocytogenes and Staphylococcus saprophyticus was very sensitive towered most date extracts than other Gram positive bacteria. Generally, Staphylococcusaureus ATCC 25923 was more resistance than other Gram positive bacteria. Whereas, Staphylococcus saprophyticus was more sensitive towered most date extracts than other Gram positive bacteria. The ethanolic extracts of the three tested cultivars (Khulase, Sheshi and Rezaz) in Biser ripening stage showed the stronger antibacterial activity by inhibiting growth ofStaphylococcus saprophyticus (the diameter of inhibition zone, 35, 30 and $37.5 \mathrm{~mm}$, respectively), also, the aqueous extracts of cultivar Khulase in Tamer ripening stage, Shashi in Biser and in Tamer stage and Rezaz in Biser

\begin{tabular}{|c|c|c|c|}
\hline Cultivars & $\begin{array}{c}\text { Ripening } \\
\text { stages }\end{array}$ & Extracts & $\begin{array}{c}\text { MIC (mg/mI) } \\
\text { Staph. saprophyticus } \\
\text { ATCC 15305 }\end{array}$ \\
\hline Khulase & Biser & Ethanol & 10 \\
\hline & Rutab & Ethanol & 5 \\
\hline & Tamer & Ethanol & 10 \\
\hline Sheshi & Biser & Water & 10 \\
\hline & & Water & 5 \\
\hline & Rutab & Ethanol & 10 \\
\hline & Tamer & Ethanol & 5 \\
\hline & & Water & 5 \\
\hline Rezaz & Biser & Ethanol & 3.75 \\
\hline & & Water & 10 \\
\hline
\end{tabular}

Table 4: Minimal inhibitory concentration (MIC) of most effective date cultivars extracts at various ripening stages against Staph. saprophyticus ATCC 15305. stage showed the stronger antibacterial activity by inhibiting growth of Staphylococcus saprophyticus (the diameter of inhibition zone, 29.5, 29, 29.5 and $30 \mathrm{~mm}$, respectively). Thus the ethanolic extracts of date illustrated the stronger antibacterial activity than aqueous extracts against Staphylococcus saprophyticus. The total phenols and pigments (carotenoids and anthocyanins) of date cultivars ethanol and water extracts at various ripening stages are tabulated in Table 5. The ethanolic extracts of all date's cultivars in Biser ripening stage recorded higher amount of phenols compared with the other stage (Rutab and Tamer). The methanolic extracts of Rezaz cultivar in Biser stage had highest contents of phenols (2035.3 mg/100g). Al- Qurashi [16] and Awad [17] reported that the total phenols concentration in date palm fruit sharply decreased during ripening to a low level means Biser stage containing the highest amount of phenolic compounds. Polyphenols play an important role as antibacterial activity through the precipitation of proteins and inhibition of enzymes of microorganisms [31,32]. The pigments (carotenoids and anthocyanins) in all date's cultivars increased with the increasing of ripening stages for both ethanolic and water extracts. Lutein is the major carotenoid pigment present in dates followed by $\beta$-carotene [14].Parshanth[33] and Al-Zoreky[34] proved that methanolic extract of pomegranate peels were more active than water extracts against some pathogenic bacteria. Shen[13] found antimicrobial effect of blueberry (are rich in phenolics) extracts against Listeriamonocytogenes and SalmonellaEnteritidis. The antibacterial activity of date extracts may be due to the phenolic compound which more extracted with ethanol and water than ether [2-9].

\section{Minimal Inhibitory Concentration (MIC) of extracts}

The minimum inhibitory concentration of the most active date cultivars extractsagainst the most sensitive bacteria (Staphylococcus saprophyticus) are presented in Table 4. The results shows that Staphylococcus saprophyticus was very sensitive to the lowest concentration of ethanol extract of Rezaz variety in Biser stage (MIC $3.75 \mathrm{mg} / \mathrm{ml}$ ). While these bacteria appeared medium sensitive to the ethanolic extracts of khulase cultivar at Rutab stage and Sheshi cultivar at Biser, Rutab and Tamer stage (MIC, $5 \mathrm{mg} / \mathrm{ml}$ ). However, the tested bacteria showed resistant to the other dates extracts (MIC, $10 \mathrm{mg} / \mathrm{ml}$ ). The strong effect of ethanol extract of Rezaz variety in Biserstage may be due to the higher phenolic compounds content than other extracts (Table 5).Allaith (2008) found the total phenolics at Biserwere $196 \pm 72.1$ $\mathrm{mg} / 100 \mathrm{~g}$ but at Rutab stage were $116.7 \pm 44.1 \mathrm{mg} / 100 \mathrm{~g}$ based on fresh weight. Staphylococcus saprophyticus is often implicated in urinary tract infection [35].Haman [36] found that Staphylococcus saprophyticus was found to contaminate $16.4 \%$ of the various food samples with a high prevalence of $34 \%$ in raw beef and pork.

\section{In situ antibacterial activity of extract}

Staphylococcus saprophyticus were common found in meat and carcasses as well as worker's protective gloves in slaughterhouse [36]. The survivalof Staphylococcus saprophyticus during refrigerated storage in minced camel meat medium effected by presence of ethanol extract of Rezaz variety at Biser stage ( $\mathrm{RBOH})$, (as a more effective extract) are showed in Figure 1.During storage Staphylococcus saprophyticus was not detected in non-inoculated meat used in trials. The obtained results revealed that the $\mathrm{RBOH}$ possessed an immediate inhibition $\left(0.1 \log _{10}\right.$ cycles $)$ at zero time against tested bacteria in meat. However, Staphylococcus saprophyticus was gradually increasing in control sample (meat infected by Staphylococcus saprophyticus), reaching more than $5.4 \log _{10} \mathrm{cfu} / \mathrm{g}$ after 12 days of storage. Addition of RBOH significantly reduced the count of bacteria in meat gradually during storage. The 
Citation: Saleh FA, Otaibi MM (2013) Antibacterial Activity of Date Palm (PhoenixDectyliferaL.) Fruit at Different Ripening Stages. J Food Process Technol 4: 285. doi:10.4172/2157-7110.1000285

Page 5 of 6

\begin{tabular}{|c|c|c|c|c|c|c|c|}
\hline \multirow[t]{2}{*}{ Cultivars } & \multirow[t]{2}{*}{ Ripening stages } & \multicolumn{2}{|c|}{ Total phenols $(\mathrm{mg} / 100 \mathrm{~g})$} & \multicolumn{2}{|c|}{ Carotenoids (mg/100g) } & \multicolumn{2}{|c|}{ Anthocyanins $(\mathrm{mg} / 100 \mathrm{~g})$} \\
\hline & & Ethanol & water & Ethanol & water & Ethanol & water \\
\hline \multirow[t]{3}{*}{ Khulase } & Biser & 1608.6 & 776.3 & 2.83 & 1.73 & 29.40 & 29.40 \\
\hline & Rutab & 1384.8 & 944.2 & 5.41 & 3.25 & 39.41 & 33.40 \\
\hline & Tamer & 1042.1 & 754.6 & 6.85 & 7.63 & 77.15 & 45.09 \\
\hline \multirow[t]{3}{*}{ Sheshi } & Biser & 1657.6 & 629.46 & 4.58 & 2.85 & 31.73 & 29.06 \\
\hline & Rutab & 902.2 & 511.3 & 4.16 & 3.81 & 32.40 & 47.76 \\
\hline & Tamer & 937.2 & 552.4 & 6.85 & 4.39 & 47.43 & 46.76 \\
\hline \multirow[t]{3}{*}{ Rezaz } & Biser & 2035.3 & 552.5 & 4.46 & 4.82 & 31.75 & 31.08 \\
\hline & Rutab & 879.5 & 532.1 & 5.28 & 6.17 & 92.85 & 41.41 \\
\hline & Tamer & 888.2 & 425.6 & 20.26 & 8.71 & 153.30 & 46.09 \\
\hline
\end{tabular}

Table 5: The total phenols and pigments of date cultivars ethanol and water extracts at various ripening stages.

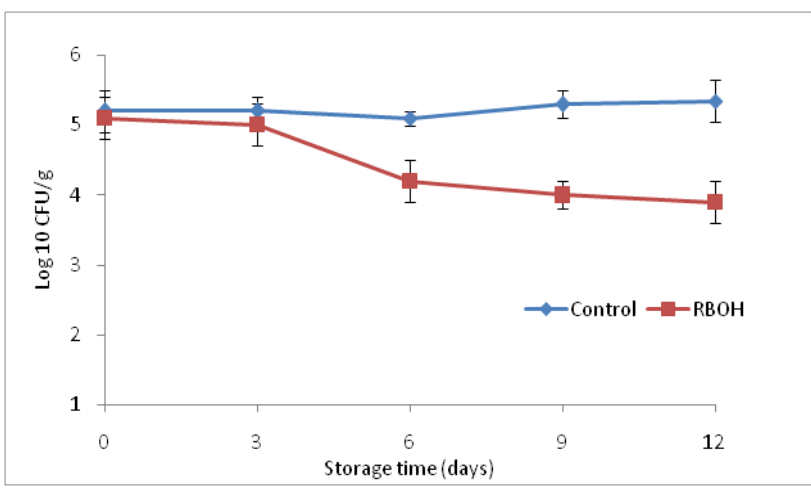

Figure 1: The survival of Staphylococcus saprophyticus during refrigerated storage in minced camel meat medium effected by presence of ethanol extract of Rezaz variety at Biser stage $(\mathrm{RBOH})$.

viable cell numbers of Staphylococcus saprophyticus remained below the inoculation level $\left(5 \log _{10} / g\right)$ until the end of storage time. The presence of RBOH reduced 1, 1.2 and $1.3 \log _{10}$ cfu/g of Staphylococcus saprophyticus after 6, 912 days of storage period, respectively, in treated meat compared to the control sample. The inhibition ability of $\mathrm{RBOH}$ in treated meat could be attributed to the impact of phenolic compounds on the pathogen. Polyphenols played an important role in protein precipitation and enzyme inhibition of microorganisms [31,32].

\section{Conclusion}

The results obtained indicate that the ethanol extract of Rezaz variety at Biser stage $\mathrm{RBOH}$ may be used for natural food preservation and may become important in the obtainment of a noticeable source of compounds with health protective potential and antimicrobial activity.

\section{Acknowledgement}

The author wishes to thank the Scientific Research Deanship in King Faisal University, Al-Ahsa, Saudi Arabia (KFU) for financial support of this study.

\section{References}

1. Davidson PM (2001) Chemical preservatives and natural antimicrobial compounds. In Food Microbiology, Fundamentals and Frontiers, (2nd Edition). pp. 593-627, American Society for Microbiology, Washington, DC.

2. Rauha JP, Remes S, Heinonen M, Hopia A, Kahkonen M, et al. (2000) Antimicrobial effects of Finnish plant extracts containing flavonoids and other phenolic compounds. Int J Food Microbiol 56: 3-12.
3. Puupponen PR, Nohynek L, Meier C, Kahkonen M, Heinonen M, et al.(2001) Antimicrobial properties of phenolic compounds from berries. J Appl Microbio 90: 494-507.

4. Zhu X, Zhang H, Lo R (2004) Phenolic compounds from the leaf extract of artichoke (Cynarascolymus L.) and their antimicrobial activities. J Agr Food Chem 52: 7272-7278.

5. Proestos C, Chorianopoulos N, Nychas GJE, Komaitis M (2005) RP-HPLC analysis of the phenolic compounds of plant extracts. Investigation of their antioxidant capacity and antimicrobial activity. J Agr Food Chem 53: 1190-1195

6. Sousa A, Ferreira ICFR, Calhelha R, Andrade PB, Valentao P, et al. (2006) Phenolics and antimicrobial activity of traditional stoned table olives "alcaparra". Bioorganic \& Medicinal Chemisty 14: 8533-8538.

7. Pereira JA, Pereira APG, Ferreira ICFR, Valentao P, Andrade PB, et al. (2006) Table olives from Portugal: phenolic compounds, antioxidant potential and antimicrobial activity. Journal Agricultural Food Chemistry 54: 8425-8431.

8. PereiraAP, Ferreira ICFR, Marcelino F, Valenao P, Andrade F, et al. (2007a) Phenolic compounds and antimicrobial activity of olive (Oleaeuropaea L. Cv. Cobranc_osa) leaves. Molecules 12: 1153-1162.

9. Pereira JA, Oliveira I, Sousa A, Valentao P, Andrade PB, et al. (2007b) Walnut (Juglansregia L.) leaves: phenolic compounds, antimicrobial activity and antioxidant potential of different cultivars. Food Chemistry Toxicology 45: 22872295

10. Fernandez M, Garcia M, Saenz M (1996) Antibacterial activity of the phenolic acid fraction of Scrophulariafrutescens and Scrophulariasambucifolia. Journal Ethno pharmacology 53: 11-14

11. Hoult J, Paya M (1996) Pharmacological and biochemical actions of simple coumarins: natural products with therapeutic potential. Gen Pharmacoloy 27 713-722.

12. Negi PS, Jayaprakasha GK (2003) Antioxidant and antibacterial activities of Punicagranatum peel extracts. Journal of Food Sciences 68: 1473-1477.

13. Shen X, Sun X, Xie Q, Liu H, Zhao Y, et al. (2014) Antimicrobial effect of blueberry (Vacciniumcorymbosum L.) extracts against the growth of Listeriamonocytogenes and SalmonellaEnteritidis. Food Control 35: 159-165.

14. Boudries H, Kefalas P, Hornero MD (2007) Carotenoid composition of Algerian date varieties (Phoenix dactylifera) at different edible maturation stages. Food Chem 101: 1372-1377.

15. Amors A, Pretel MT, Almansa MS, Botella MA, Zapata PJ, et al. (2009) Antioxidant and nutritional properties of date fruit from elche grove as affected by maturation and phenotypic variability of date palm. Food SciTechnollnt 15: 65-72.

16. Al-Qurashi AD (2010) Physico-chemical changes during development and ripening of 'Helali' date palm fruit. Journal of Food Agriculture and Environment 8: 404-408.

17. Awad, MA (2011) Growth and compositional changes during development and ripening of early summer 'Lonet-Mesaed' date palm fruits. Journal of Food Agriculture \& Environment 9:40-44.

18. Amira EA, Behija SE, Beligh M, Lamia L, Manel I, et al. (2012) Effects of the 
Citation: Saleh FA, Otaibi MM (2013) Antibacterial Activity of Date Palm (PhoenixDectyliferaL.) Fruit at Different Ripening Stages. J Food Process Technol 4: 285. doi:10.4172/2157-7110.1000285

ripening stage on phenolic profile, phytochemical composition and antioxidant activity of date palm fruit. Int J Food Sci Tech 60: 10896-10902.

19. Eid NMS, Al-Awadi B, Vauzour D, Oruna-Concha MJ, Spencer JPE (2013) Effect of cultivar type and ripening on the polyphenol content of date palm fruit. J Agr Food Chem 61: 2453-2460.

20. Al Farsi M, Alasalvar C, Morris A, Baron M, Shahidi F (2005) Comparison of antioxidant activity, anthocyanins, carotenoids, and phenolics of three native fresh and sun-dried date (Phoenix dactylifera L.) varieties grown in Oman. J Agr Food Chem 53: 7592-7599.

21. Mansouri A, Embarek G, Kokkalouc E, Kefalas P (2005) Phenolic profile and antioxidant activity of the Algerian ripe date palm fruit (Phoenix dactylifera). Food Chem 89: 411-420.

22. Allaith AA (2008) Antioxidant activity of Bahraini date palm (Phoenix dactylifera L.) fruit of various cultivars. Int J Food Sci Tech 43:1033-1040.

23. Chaira N, Smaali MI, Martinez TM, Mrabet A, Murcia MA, et al. (2009) Simple phenolic composition, flavonoid contents and antioxidant capacities in watermethanol extracts of Tunisian common date cultivars (Phoenix dactylifera L.). Int J Food SciNutr .Suppl 60: 316-329.

24. Lahtinen SJ, Jalonen L, Ouwehand AO, Salminen SJ (2007) Specific Bifidobacterium strains isolated from elderly subjects inhibits growth of Staphylococcus aureus. Int J Food Microbiol 117:125-128.

25. Boyer J, Hai LR (2004) Apple phytochemicals and their health benefits. Nut J 3: 1-15.

26. Revilla E, Ryan JM, Martin-Ortega G (1998) Analysis of grape and wine anthocyanins by HPLC-MS. J Agr Food Chem 46: 4592-4597.

27. Mosquera MML, Rejano NL, Gandul RB, Sanchez GA, Garrido FJ (1991) Colo pigment correlation in virgin olive oil. Journal of the American Oil Chemists' Society 68 : $332-336$
28. Wanger GJ (1979) Content and vacuole/extra vacuole distribution of neutral sugars, free amino acids, and anthocyanins in protoplasts. Plant Physiol 64 88-93.

29. SAS. (1989) Statistical Analysis Systems, User Guide Statistics, Version 6.0. SAS Inst., Inc., Cary, NC, USA.

30. Ahmad I, Beg AZ (2001) Antimicrobial and phytochemical studies on 45 Indian medicinal plants against multi-drug resistant human pathogens. J Ethnopharmacol 74: 113-123

31. Naz S, Siddiqi R, Ahma, S, Rasool S, Sayeed S (2007) Antibacterial activity directed isolation of compounds from Punicagranatum. Journal of Food Sciences 72:341-345.

32. Fan W, Chi Y, Zhang S (2008) The use of a tea polyphenol dip to extend the shelf life of silver carp (Hypophthalmicthysmolitrix) during storage of ice. Food Chem 108: 148-153.

33. Parshanth D, Asha M, Amit A (2001) Antibacterial activity of Punicagranatum Fitoterapia 72: 171-173.

34. Al-Zoreky NS (2009) Antibacterial activity of pomegranate (Punicagranatum L.) fruit peels. International Journal of Microbilology 134: 244-248.

35. Kuroda M, Yamashita A, Hirakawa H (2005) Whole genome sequence of Staphylococcussaprophyticus reveals the pathogensis of uncomplicated urinary tract infection. Proceeding of the National Academy of Sciences, USA 102: 13272-13277.

36. Haman P, Ringertz O, Eriksson B, Kvarnfors P, Andersson M, et al. (1990) Staphylococcus saprophyticus found to be a common contaminant of food. $J$ Infection 21:11-19. 